\title{
Experimental Study of The Use of Spiderman Game Media (Spinner of Education for Mankind) In Learning Sociology for Improving Student Learning Outcomes
}

\author{
Anna Rusmiyati \\ SMAN 1 Pulung, Ponorogo \\ e-mail: aannarusmiyati2@gmail.com
}

\begin{abstract}
The aim of this research is to: (1) be able to vary the methods of learning in the classroom, (2) create fun and enjoyable learning by using spiderman games. That way it can make it easier to understand and comprehend learning material so that it improves student learning outcomes in sociology subjects at SMA Negeri 1 Pulung. This study uses a quasi experimental design method (quasiexperimental) with a form of nonequivalent control group design. The population in this study were students of class XI IPS (social science) 1 and XI IPS (social science) 3 of SMA Negeri 1 Pulung, totaling 68 students. The sample used in this study was the entire population, namely two classes from class XI of the IPS (social science) program. All class, divided to, one class is grouped into an experimental class (35 students) and another class as a control class (33 students). The experimental class applies the "spiderman" learning media and the control class applies the power point learning media. This research data collection using tests and documentation. Data collected are pre-test and post-test. Data analysis techniques using quantitative descriptive. The results showed that: (1) based on the results of the calculation at the time of the pretest compared to the post test showed that the learning outcomes of the experimental class students increased from 45.16\% to $80.7 \%$ who passed the KKM (minimum completeness criteria), while the learning outcomes of the control class from $20 \%$ when the pretest becomes $50 \%$ at the post test. Based on these results show evidence that learning media "spiderman" is better than learning media power point, (2) learning media "spiderman" has a significant influence on learning outcomes of students of class XI IPS (social science) in SMA Negeri 1 Pulung that is equal to $35.54 \%$. With a positive number which means that the average post test value of the experimental class is greater than the control class. This shows that the learning media "spiderman" has an influence on improving student learning outcomes in sociology subjects.
\end{abstract}

Key words : Experimental study, Spiderman game, Media

\section{INTRODUCTION}

Education is a tool or a means to raise the quality and degree of the nation. A great nation is a nation of strong character, integrity, hardworking, disciplined, honest, independent, high nationalism and religious. The Indonesian people themselves have strong cultural and character values and a strong foundation of religious beliefs. This great potential can become the foundation of an ideal education. In addition, education is one of the most important pillars in building the quality of the nation's generation. The quality of the nation's generation can be judged by its character and high productivity. The literal character of the generation and must have a high struggle in achieving the quality of life is the ideals of the nation and state in full human development.

At each implementation of teaching and learning activities emphasizing how to create models and methods of learning that are creative, innovative, and do not cause boredom among students. In addition, the most important thing is the improvement of students' learning outcomes and the achievement of learning objectives. The learning 
process is needed by placing students as the center stage performance, which is an interesting learning process so students can respond to learning with a pleasant atmosphere that is also fun, and not a boring atmosphere.

SMAN 1 Pulung, Ponorogo is one of the top schools in the village of Pulung Merdiko, Pulung District, about $15 \mathrm{~km}$ east of Ponorogo. When riding a motorized vehicle it takes about 15-20 minutes from the city of Ponorogo to arrive at SMAN 1 Pulung, Ponorogo. The location of SMAN 1 Pulung, Ponorogo which is under the foot of the southern part of Mount Wilis and the majority of its population is agriculture is a challenge in this case in the world of education. This school is located in a rural area so it will be very different from the input of human resources in urban areas.

The majority of SMAN 1 Pulung, Ponorogo student parents are working as farmers, traders, construction workers, and even those who work as overseas workers. But what needs to be given a thumbs up is the enthusiasm and motivation of those SMAN 1 Pulung, Ponorogo students to continue working towards continuing education. In accordance with the motto of this school, which is "Filially Gaining Achievement". One of the problems of learning in this school is the still unstable signal constraints in accessing information through the internet. That's why learning by utilizing the internet and cellphone networks is sometimes difficult to use in this school due to signal factors. Even so, it is not an obstacle for the three of us with these conditions even spurred to create creative, innovative and attractive learning methods.

Determined to improve student learning, the three of us created a new learning method in the form of the game media "Spiderman" (Spinner of Education for Mankind). Particularly for sociology subjects, with this spiderman media students are expected to prefer sociology subjects and enthusiasm in learning so that it has an impact on improving learning outcomes. In SMAN 1 Pulung, Ponorogo, sociology is one of the subjects of specialization in social majors. As one of specialization subjects, the existence of sociology should really be in demand by students. But in reality, some of their students still consider sociology to be boring, saturating and always make them sleepy in class. So that learning can not be maximized and not in accordance with the learning objectives written in the learning implementation plan (RPP). Things like this that can not be felt by a teacher, where the teacher is not responsive to the classroom atmosphere and the learning methods used.

Departing from the previous statement that "sociology is a sleepy subject" then a new learning method was created. It is hoped that learning is relevant to educational changes where learning must be able to make students more enthusiastic, enthusiastic and also have an impact on improving learning outcomes. This is what needs to be the subject's attention.

The low learning motivation of students so far is suspected because the teacher's learning methods are monotonous, boring, and less innovative. Students are not given the opportunity to think and develop their memory in dealing with a problem. All information knowledge is only focused on one source, namely the teacher. This is in line with the low opinion of learning outcomes because the classroom atmosphere tends to be teacher-centered so that students become passive (Trianto, 2007: 6). Monotonous learning methods, such as lectures or powerpoint displays that are less attractive gradually begin to be shunned by students. Because in addition to the material presented does not encourage students to think critically, creatively, collaboratively, and communicatively it also results in boredom and makes them sleepy during learning. 
Besides that, the method as stated above makes students more passive just sit and watch and also listen to the teacher present the material.

Willingness is a powerful motivation for a person to make a change. Neither on the teacher's part, it is expected to be able to create innovative learning methods so that students will be more active and creative in learning activities in accordance with established educational goals. From the description above, then the problem form appears, namely how is the use of spiderman (spinner of education for mankind) media in sociology learning to improve student learning outcomes?

The objectives of this research include (1) Can vary the methods of learning, (2) Create fun and enjoyable learning by using spiderman games so that learning materials are more easily understood by students, (3) Developing the ability of teachers in creating creative learning methods, innovative, and communicative, (4) Helping students develop their abilities both individually and in groups so that they are able to solve problems, (5) As one of the means to realize the increase in value of students in social group material.

While the benefits of this research are (1) Can develop insight about learning methods, (2) Can find out the responses and interests of students to the methods presented by the teacher when the teaching-learning process, (3) Increase the competence of students in solving problems, (4) Improving student achievement in sociology lessons, (5) Increasing teacher motivation to create new learning methods that are more innovative and creative

\section{RESEARCH METHODS}

The method used in this study is a quasi experiment with a quantitative approach. In the quasi experiment method, researchers try to determine whether a treatment affects the results of a study. This influence is assessed by applying certain treatments to one group (treatment group) and not applying it to the other group (control group), then determining how the two groups determine the final outcome (John W. Creswell, 2014: 19).

In this study, the quasi-experimental method uses the nonequivalent control group design, in which the experimental group (A) and the control group (B) are selected without a random placement procedure (without random assignment). In the two groups, both pre-test and post-test were conducted.

Operational Definitions

Learning Outcomes

Learning outcomes are changes in behavior or increased understanding of knowledge and experience as a result of the learning process. Learning outcomes are measured using tests (pre test and post test). In this study, learning outcomes are considered as the dependent variable.

Learning Media

Learning media is something that can be used to deliver material that is quite difficult to convey if only delivered with words or explanations on the board. The media used are spiderman media for the experimental class and power point for the control class. In this study, instructional media is considered as an independent variable.

Pre test and Post test

Pre test is the initial test given before treatment is given. This pre-test is given both to the experimental class and the control class, so it is known the extent of the 
student's learning outcomes before being given treatment. This pre test stage is also used to test instruments in the form of tests.

Post test is the final test given after treatment is given. Post test was used to determine the learning outcomes of the control class and experimental class after treatment.

\section{Control Class and Experiment Class}

The control class is a class in the learning process using power point media, while the experimental class is a class in the learning process using spiderman media.

\section{Place and Time of Research}

The study was conducted in July 2019 to August 2019 in class XI IPS (social science) in SMA Negeri 1 Pulung, Ponorogo. The schedule for conducting the research was adjusted to the schedule of sociology lessons in class XI IPS (social science) in SMA Negeri 1 Pulung.

Population and Samples

Population The population in this study were students of class XI IPS (social science) SMA Negeri 1 Pulung. This class XI IPS (social science) student consists of 3 classes, namely class XI IPS (social science) 1 consisting of 33 students, class XI IPS (social science) 2 consisting of 33 students, and class XI IPS (social science) 3 consisting of 35 students 2. Samples The sample used in this study were two classes from class XI IPS (social science) SMA Negeri 1 Pulung, namely class XI IPS (social science) 1 and XI IPS (social science) 3 . Of the two classes, one class is grouped into an experimental class, XI IPS (social science) 3 and another class as a control class, XI IPS (social science) 1 .

Research Instruments

There are two kinds of instruments used for research, namely learning media and tests (pre-test and post-test). Learning media is used to differentiate between the control class and the experimental class, while the test is used as a reference to determine students' abilities in pre-test and post-test by working on questions of sociology with the form of questions in the form of a description or essay.

\section{Instrument Testing}

Test Validity, the validity test of instructional media, both in the form of spiderman and power point media, it is carried out by consulting and asking the teacher of sociology for consideration and systematically examining whether these media are in accordance with the material available in the subjects of sociology. After consultation and improvement, the learning media is declared valid. According to Sugiyono (2014: 182) for instruments in the form of tests, content validity testing can be done by comparing the contents of the instrument with the subject matter that has been taught. A teacher who gives a test outside the subject matter, means the instrument has no content validity. Technically, content validity testing can be helped by using the instrument lattice.

Reliability, the test is said to be reliable if it gives permanent results when tested multiple times. A test is said to be reliable if the results of the test show determination. In other words, if students are given the same test at different times, then each student 
will remain in the same rank (ranking) in the group (Suharsimi Arikunto, 2013: 74). Instrument reliability testing can be done externally or internally. Externally testing can be done with a test-retest (stability), equivalent, and a combination of both. Internally instrument reliability can be tested by analyzing the consistency of the items on the instrument with certain techniques (Sugiyono, 2011: 354). The method used to test the reliability of instruments is internal consistency, carried out by testing the instrument once and then analyzing it with a particular technique. The results of the analysis can be used to predict the reliability of the instrument.

Research Implementation

The implementation of this research went through several stages, namely:

Preparation Stage

The preparation phase is the initial stage that is prepared before conducting research. This preparation phase includes: a. Observation, b. Making a research proposal, c. Making research instruments, d. Research permission

\section{Experiment Implementation Stage}

So that experimental research is said to be valid, it requires controlling extraneous variables that can affect the dependent variable. An experimental study is said to be valid if the results obtained are the result of manipulation of independent variables, the results can also be applied outside the experimental settings.

Evaluation and Report Preparation Phase

Evaluation stage is the stage of research regarding data processing on student learning outcomes. In this evaluation phase, the results of the pre-test and post-test experimental class were compared with the control class for the preparation of this research report. In the preparation of this report, the results emphasized are the comparison between the results of the experimental class posttest with the control class, so that it can be known whether the learning outcomes of students who use the media of learning spiderman media are better than the learning outcomes of students who use power point learning media.

\section{Data Collection Methods}

Data collection is the methods used to collect data in research. Data collection methods in this study are observation (notes) and tests. Observation is used to differentiate between learning media in the form of spiderman media and learning media in the form of power points, while the test is used to measure learning outcomes between students of the experimental class and the control class. The data collection technique used for observation is to observe whether spiderman media and power point media are in accordance with the specified syllabus. The technique used for the test is to use a pre test and post test. The test is carried out twice, namely before (pre test) and after (post test) students are given treatment (treatment) to find out the improvement in student learning outcomes

Data Analysis Techniques

Data analysis techniques are intended to find answers to research questions or about problems that have been previously formulated. The approach used in this 
research is a quantitative approach, then the data analysis used is a statistical data analysis technique.

\section{FINDING AND DISCUSSION}

\section{A. Spinner / Spiderman Media in Learning}

Creating a learning method is important for a teacher. The method of learning itself means the process of delivering a learning material to students which is carried out systematically and regularly by the teaching staff or teacher so that the learning objectives that have been set can be achieved properly. Creative, communicative, and innovative learning methods are methods expected by students. Because that way, the teaching-learning process becomes more fun and not boring so that students can more easily absorb the lesson. Learning methods with lecture style are increasingly abandoned and unattractive to students because only boredom and boredom are raised.

On this occasion, we tried to apply a new learning method by using spiderman play media in learning sociology. This game media basically uses media similar to spinner objects. The purpose of learning using spiderman media, among others, is to make the delivery of material using other new media so that students are more interested and enthusiastic about following the teaching and learning process. Besides that, the realization of KDP or the strengthening of character education, including cooperation, communicative, and creative learning. This method emerged due to several underlying factors, including the material that could not be conveyed optimally because the learning methods were not in accordance with the conditions of the class or the students at that time. In addition, it is the reluctance of teachers to try new learning methods that are more innovative and creative. They tend to prefer the style of teaching which is actually not desired by the students who are considered to be old school not following the times. To carry out learning with spiderman media, the most important first step is to prepare (1) The materials include used cardboard, paperboard, buffalo paper, glue, bolts, duct tape, photo print related to sociology, and cellphone octopus adhesive; (2) The tools consist of scissors, rulers, pencils, markers, screwdrivers, and cutters. After the materials and tools are ready the next step is the process of making a media spinner.

The steps to work on the spinner are (1) Measure the carton with a ruler to adjust the size, (2) After making a circle using the term, (3) Then mark it using a pencil, (4) After that cut it into a circle according to the desired size, (5) What should not be forgotten is to cut various colored buffalo paper with triangles according to the size of the circle, (6) The buffalo paper that was cut out by the triangle was then ready to be attached to the circle that had been made, (7) While waiting for it to dry, prepare the base to stick the bolt and spinner base, (8) Then, bolt the prepared base, (9) When ready, proceed to the circle, (10) Attach the cardboard circle with the cardboard circle, don't forget to give 10 cavities cavity section, (11) Each cavity is given a dividing line and does not forget to be given a cover.

For the next stage of work, (12) Plug the circle into the right bolt in the middle, (13) Do not forget to stick the adhesive on the back of the spinner's base, (14) Also do not forget to stick the arrow, (15) Then check the spinner if the spinner is embedded with the right position, (16) If it is exactly as expected, it's time for decking such as the attachment of photographs relating to sociological material, (17) Spinner can also be crepe paper to form decorations such as ribbons, flowers, or others according to creativity to make it look more attractive, (18) Don't forget that the upper right hand 
corner can also be perforated and then given a rope so that when using learning in the spinner class it can be hung or cantified, (19) If everything is finished, the spinner media can be used for learning sociology in class. The final result of spinner media is really very interesting both in appearance, model and content. No less interesting is when posted on the blackboard in front of the class used as learning media and can be seen by all students who are following the teaching and learning process.

\section{B. Problem Card}

This is one of the important media in learning with spinner media. This card is in the form of several questions that must be answered by each group. Made from manila cardboard which is cut into ten boxes. Then written with some questions related to the material, namely social groups. After all the cards written by the question then folded inserted into the spinner. The question is what makes the teacher, while students are tasked with discussing finding answers to each question from the question card. The existence of this question card is very important, because without this question card the implementation of learning with the media spinner cannot be carried out.

\section{Social Group Materials}

Social conflict is one of the materials in class xi specializing in odd semester social sciences. This material is very interesting because humans are essentially other than individual creatures as well as social beings. From birth until we die, we are members of various social groups. When we were born, it has become part of a group called the family. Automatically, we have also become members of ethnic groups, ethnic groups, members of neighboring neighborhoods, community units, and a larger member, namely the Republic of Indonesia.

In the next stage, when the interaction we do is not limited to the family, then we begin to become members of other groups such as peer groups. After reaching school age, we will become members of formal groups, namely schools. At this stage, we can also become part of the student council group, Boy Scouts, Youth Red Cross (PMR), and others. After leaving school, we will also join other groups in various fields of life, such as groups in the economic field (as company employees), religious groups by becoming members of religious groups, economic groups (band members), politics (as a member of one political party), and others in the field

That's how the fabric of the flow of human life into social creatures and members of social groups. During the process of life, people will become part of social groups. Humans become members of social groups because there are several goals, among others are (1) Encouragement to maintain life, (2) Desire to continue offspring, (3) Desire to improve work efficiency and effectiveness, (4) Practical, intellectual, and experience emotional, (5) Equality of interest, (6) Equality of descent, (7) Equality of area, (8) Equality of physical characteristics

\section{Spiderman Media In sociology Learning}

The learning method using the spiderman game media is the latest breakthrough method that we created with several objectives, namely (1) Can vary the methods of learning, (2) Create a fun and enjoyable learning by using a spinner game so that the learning material is more easily understood by students, (3) Developing the ability of teachers to create creative, innovative and communicative learning methods, (4) Assist students in developing their abilities both individually and in groups so that they are 
able to solve problems (5) As a means to realize learning objectives in social group material.

It's really fun learning with this spiderman media. The majority of students really enjoyed, were enthusiastic, and were enthusiastic in implementing sociology learning. Nobody is sleepy in class, even the average student is able to learn in terms of cooperation, communication, and creativity. Broadly speaking, the steps taken in learning by using spiderman media are: (1) The teacher prepares the learning media, namely spinners and LCD for short video playback about social group material (2) Classes are divided into five groups where each group consists of $5-6$ people, (3) The teacher starts playing the video and each group listens to it, (4) Each group will write briefly about the contents of the video, (5) Next, a representative of one person from each group advances to carry out the game spinner, (6) The five students representing the group to the spinner media that are already installed on the board, (7) The first group that starts to spin the spinner and continued the next group, (8) The first group that gets to spin the spinner at the beginning then gets ready to spin the spinner and the spinner will move around then stop at one of the colors or parts on the spinner, (9) The spinner part that is pointed by a needle or arrow after being turned and stops at one part or the color above the spinner, then that is the task of the rotating group to take the question card pieces inside the spinner. This will continue until the five groups get time to spin the spinner and take the question cards that are in the spinner and read the questions or questions addressed to the group. In the next stage, (10) One of the group members takes the questions in the spiner, (11) Then goes to the group to submit some questions that must be responded to and find the answers, (12) Give about twenty minutes to each group discuss in search of answers to the questions in the spinner, (13) After twenty minutes is finished then the results of the discussion work from each group is handed over to the teacher or teacher, (14) Then the teacher will hold a lottery to determine which group will advance first for presentations, (15) Each group will present the results of the discussion alternately, (16) And the group that does not advance the presentation will give a response, (17) Responses will be given alternately by groups that do not appear in front, (18) After all presentations, the teacher will give an assessment of the results of the discussion and appearance of the presentation in front of the class, (19) Each to the group will give a conclusion to the discussion of the material discussed on that day, (20) The teacher at the end of the lesson will give an assessment.

\section{E. Use of spiderman Media In Improving Student learning Outcomes}

Making good and effective learning media is not measured by the high cost of the material and how complicated it is. However, the most important factor is how far the success of learning media can be a bridge for students to understand the learning material, increase the excitement of their learning, and also the results of their learning. Therefore, making a good and effective media needs to pay attention to three things, namely the material to be delivered, how to explain the material and the characteristics of students.

Attractive learning media is one of the good and effective learning media. Attractive learning media is not limited to an attractive appearance (color or shape), but most importantly, how far the media can involve students to be active in the learning process in class. The teacher is only as a referee or a place to ask if students experience difficulties during the learning process in class. And at the end, the use of learning media can improve student learning outcomes much better than before. This attractive 
media is what we are trying to make in this study. We don't just make "spiderman" media with attractive colors and images related to social group material, but also involve students in classroom learning. Students look as if playing but in essence learn a material.

To be able to assess the extent to which the "spiderman" learning media is effective in increasing the participation of students in the teaching and learning process in the classroom and also improving learning outcomes, we compare it with other learning media that are commonly used by teachers, namely power point media.

Based on the results of our research in class XI IPS (social science) 1 and XI IPS (social science) 3, SMAN 1 Pulung, Ponorogo, it turns out that the "spiderman" learning media is more effective in increasing the participation of students and achievements in the process of teaching and learning activities.

\section{Student Participation}

Based on the results of research in class XI IPS (social science) 1 and XI IPS (social science) 3, learning media "spiderman" was able to increase the role of students in teaching and learning activities in class when compared to the power point media. The aspects that appear in the participation of students in teaching and learning activities include

\section{A. Bidirectional}

The principle of "spiderman" learning media is learning while playing. Who is playing? Of course, students who play. They must explain and answer questions related to the pictures in "Spiderman". Besides that, by turning the "spiderman" wheel and when it stops at a point, students will take the question cards that are in the spderman to then be discussed with the group and then presented in the form of presentations in front of the class

Therefore, this learning media creates two-way communication between students of class XI IPS (social science) 3 and the teacher when learning takes place in class. That is, the teacher not only provides material before the game, but students are also required to master the material if they want to be able to play with this learning media. The teacher is only as a referee and the facilitator is also a mediator when each group appears presenting the results of their thoughts. In addition, students in one group can exchange questions to discuss questions in the box in "Spiderman". While when delivering the results of the discussion, where each group will advance and other groups will respond. This is where you will see the ability of the 4.0 century in learning including $4 \mathrm{C}$ (Critical Thinking, Communicative, Collaboration, and Creative). Students with enthusiasm and actively participate in the discussion until the bell time signals the end of learning.

Unlike the power point. This learning media only creates a one-way communication system. The teacher is only a source of information in front of the class. Learners only see and listen to the material provided by the teacher. Students just sit on their benches which sometimes these conditions actually cause the atmosphere to be bored and boring. And consequently, students in class XI IPS (social science) 1 are generally passive during teaching and learning activities taking place because of the power point learning method. 


\section{B. The Excitement of Student Learning}

"Spiderman" learning media is essentially a learning medium that invites students to learn while playing. This is what makes the enthusiasm of students learn in class XI IPS (social science) 3 high. This condition appears from their high enthusiasm and enthusiasm during the learning process in the classroom. It is seen that around $90 \%$ of students in class XI IPS (social science) 3 scramble to run the "spiderman" wheel and explain the picture printed on the wheel. Different students of class XI IPS (social science) 1 who use power points. Their enthusiasm for learning can be said to be low during teaching and learning activities. This condition is seen from the majority of students who are sleepy when teaching and learning activities take place. Some of them even asked permission to go to the bathroom to wash their faces so they would not get sleepy. Besides being sleepy, the power point media also made some students not focus on paying attention when the teacher explained the material. Some of them draw on paper

\section{Learning Outcomes}

The use of learning media "spiderman" can not only increase the enthusiasm of students' learning, but also can improve their learning outcomes when compared to power points. This can be seen from the results of the pre test and post test From the results of these two tests, it appears that there was a significant increase in the learning outcomes of students of class XI IPS (social science) 3 compared to the improvement in learning outcomes of students of class XI IPS (social science) 1 with different learning media. 20 From the population of class XI IPS (social science) 3 as many as 35 students, taken in this study were 31 students. This is due to 4 other students not attending school due to illness and permission. Based on 31 students who took the post test, as many as 25 students, or equal to $80.7 \%$, experienced an increase in grades after learning with the "spiderman" learning media. The values they get are above the Minimum Completeness Criteria (KKM), which is 70. The other 6 students or as much as $19.35 \%$ are still below the Minimum Completeness Criteria (KKM). This condition has a significant increase in value when compared with the pre test results of students. Of the 31 students, those whose grades reached above Minimum Completeness Criteria (KKM) were only 14 students, or $45.16 \%$. While the rest, namely 17 students or $54.84 \%$, the value is still below the Minimum Completeness Criteria (KKM). Thus, as many as 11 students or $35.48 \%$, experienced an increase in value after the delivery of material through "spiderman" learning media. The following is a collection of pre-test and post-test scores of class XI IPS (social science) 3 students of SMAN 1, Ponorogo.

Different conditions can be seen from the post test results of class XI IPS (social science) 1 which uses power point learning media. Of the total 33 students in class XI IPS (social science) 1, only 20 students were respondents. This is because at the time of data collection, 2 students did not enter, 8 students took the pre test but did not take the post test, and 3 other students took the post test but did not take the pre test. Thus, we did not include 13 students in the analysis of the results of the study.

Of the 20 students, based on a comparison of the results of the post-test with the pre-test, the decrease in students is not yet complete or is still below the Minimum Completeness Criteria (KKM), not too much. If at the time of pre-test students who are still below the Minimum Completeness Criteria (KKM) as many as 16 people, after the post-test the number of students who have not finished is only reduced by 6 people or 
there are still 10 students whose grades are still below the Minimum Completeness Criteria (KKM).

When it is patented, the composition is not much different. If during the pre-test the value of students who are still below the Minimum Completeness Criteria (KKM) is $80 \%$, after being given material by using points, the number of students who are still below the Minimum Completeness Criteria (KKM) becomes 50\%. The following are the pre-test and post-test scores of students in class XI IPS (social science) 1 using power point learning media

\section{CONCLUSIONS}

When looking at the results of the data analysis above, it appears that the "spiderman" learning media is more effective in improving both the excitement of learning and the value of students in the classroom. Learning media are created with several objectives including, being a means to help students easily understand the subject matter delivered by the teacher, foster enthusiasm in the learning process, and also improve student learning outcomes. If all this time, the learning media presented by the teacher are plural, namely the lecture method and power point, then on this occasion we offer a new method in learning sociology, the game media "Spiderman" (Spinner of Eduction for Mankind). This method is a game using a tool similar to a spinner object. The way to play is to spin the spiderman wheel then take the questions in the spiderman box when the wheel stops and the arrow needle points to a point. Then the question was read by the representative and discussed together by the group to find the answer solution Games with spiderman media are very exciting when used while learning. Students are very motivated and enthusiastic to follow it. They tend to be active in moving, asking, answering, and responding to it so that class conditions become more dynamic. Curiosity on the question of what is obtained from the spiderman machine becomes something interesting for students. Different from learning with the power point method. Where students just sit to listen and see the teacher's explanation in front of the class. And what happens is one-way communication not two-way.

Suggestion As beginners, the three of us realized there were still many shortcomings in writing this teacher's writing. Besides the busyness of the main task of teaching is also due to other activities that can not be abandoned. If for the sake of perfection of this writing, please give constructive criticism and suggestions. And we hope that the writing of this work can provide insight and knowledge to the world of education

\section{REFERENCES}

Banks, James. A. 1990. Teaching Strategies For The Social Studies (Inquiry, Valuing, And Decision Making). Longman. New York and London

Degeng, I Nyoman Sudana.2008. Teori Pembelajaran 2 (terapan). Hand Book . Program Pasca Sarjana. Universitas Kanjuruhan Malang.

Degeng, I Nyoman Sudana.2005. Teori Pembelajaran 1: Taksonomi variabel. Hand Book . Program Pasca Sarjana. Universitas Kanjuruhan Malang

Arief S. Sadiman, et al. 2012. Educational Media. Jakarta: PT. Raja Grafindo Persada

Cecep Kustandi \& Bambang Sutjipto. 2013. Learning Media; Manual and Digital. Bogor: Ghalia Indonesia 
Creswell, John W. 2014. Research Design, Qualitative, Quantitative, and Mixed Methods Approaches. Translator Achmad Fawaid. Yogyakarta: Student Library

Dimyati and Mudjiono. 2009. Learning and Learning. Jakarta: Rineka Cipta, 2009

Emzir 2012. Quantitative and Qualitative Education Research Methodology. Jakarta: Rajawali Pers

Hujair A.H. Sanaky 2013. Interactive-Innovative Learning Media. Yogyakarta: Kaukaba In the middle

Indriana, Dina. 2011. Variety of Teaching Media Aids. Yogyakarta: DIVA Press

Kun Maryati / Juju Suryawati. 2017. Book Sociology of Social Sciences Specialization Group for SMA / MA Class XI. Jakarta: Esis

Lia Candra Rufikasari. 2016. Sociology Student Book Specialization in Social Sciences for SMA / MA XI. Surakarta: CV Mediatama

Purwanto. 2009. Evaluation of Learning Outcomes. Yogyakarta: Student Library

Sri Subekti, 2018. Printing Smart Generation Through Critical Thinking Learning. Surabaya: CV. Copyright Media Education

Sri Subekti, 2018. Becoming a Productive Innovative Teacher: A Guide to Designing Innovative-Productive Learning in accordance with the 2013 Curriculum. Surabaya: CV Cipta Media Education

Sugiyono 2011. Statistics for Research. Bandung: CV. Alfabeta

Sugiyono 2014. Educational Research Methods (Quantitative, Qualitative Approach, and R\&D). Bandung: CV. Alfabeta

Suharsimi Arikunto. 2013. Basics of Educational Evaluation. Jakarta: PT. Earth Literacy

Sutrisno Hadi. (2015). Statistics. Yogyakarta: Student Library

Trianto Ibnu Badar Al-Tabany, 2014. Designing Innovative, Progressive, and Contextual Learning Models. Jakarta: Learning and Learning: Oriented Education Process Standards. Jakarta: PT Kharisma Putra Utama

https://m.detik.com/health/berita-detikhealth/d-3495507/begini-cara-pakai-fidget-

spinner-mainan-kekinian-untuk-kendalikan-stres

http://www.livescience.com/58916-fidget-spinner-faq.htm 